\title{
Hubungan Kesiapan Mental Dan Kepercayaan Diri Dengan Kinerja
} Wasit Futsal

\section{The Relationship Between Mental Readiness And Self-Confidence With The Performance Of Futsal Referees}

\author{
Deswita Supriyatni ${ }^{1}$, Asep Suhendar ${ }^{2}$ \\ ${ }^{1,2}$ Pendidikan Jasmani Kesehatan Dan Rekreasi, STKIP Pasundan Cimahi, Jl. Permana No. 32 B \\ Kota Cimahi, Jawa Barat, 40512, Indonesia
}

\begin{abstract}
Abstrak
Dalam penelitian ini penulis mempunyai tujuan, yaitu: ingin mengetahui hubungan antara kesiapan mental dan kepercayaan diri dengan kinerja wasit futsal. Metode penelitian yang digunakan dalam penelitian ini adalah metode kuantitatif dengan pendekatan korelasional dengan instrument penelitian menggunakan angket. Angket yang digunakan adalah angket tertutup. maksudnya agar semua jawaban yang diberikan oleh responden lebih mudah untuk dinilai karena semua alternatif jawaban telah ditentukan terlebih dahulu Dalam angket tersebut diberikan alternatif jawaban pada sampel, penulis menggunakan skala likert atau dikenal dengan skala sikap. Temuan dari penelitian ini bisa dijadikan landasan teoritis sebagai penelitian pendahuluan. Populasi yang digunakan dalam penelitian ini adalah seluruh wasit yang aktif memimpin pertandingan futsal di Kabupaten Bandung Barat sebanyak 9 wasit. Sedangkan yang dijadikan sampel adalah wasit futsal yang aktif memimpin di Kabupaten Bandung Barat sebanyak 9 wasit. Penentuan sampel menggunakan teknik total sampling. Berdasarkan hasil pengolahan dan analisis data menggunakan analisis korelasi ganda, mengenai hubungan kesiapan mental dan kepercayaan diri dengan kinerja wasit futsal dapat di Tarik kesimpulan sebagai berikut: terdapat hubungan antara kesiapan mental dan kepercayaan diri dengan kinerja wasit futsal
\end{abstract}

Kata kunci: Kesiapan Mental, Kepercayaan Diri, Kinerja Wasi Futsal.

\begin{abstract}
In this study the author has a goal, namely: wanting to know the relationship between mental readiness and self-confidence with the performance of futsal referees. The research method used in this study is a quantitative method with a correlational approach with the research instrument using a questionnaire. The questionnaire used is a closed questionnaire. In the questionnaire given alternative answers to the sample, the author uses a Likert scale or known as the attitude scale. The findings of this study can be used as a theoretical basis for preliminary research. The population used in this study were all referees who actively lead futsal matches in West Bandung Regency as many as 9 referees. While the sample is futsal referees who actively lead in West Bandung Regency as many as 9 referees. Determination of the sample using a total sampling technique. Based on the results of data processing and analysis regarding the relationship between mental readiness and self-confidence with the performance of futsal referees, the following conclusions can be drawn: there is a relationship between mental readiness and self-confidence with the performance of futsal referees. The contribution of mental readiness and self-confidence to the performance of futsal referees is $66.8 \%$.
\end{abstract}

Keywords: Mental Readiness, Confidence, Futsal Referee Performance

Correspondence author: Deswita Supriyatni/Asep Suhendar, STKIP Pasundan Cimahi, Indnnesia 


\section{PENDAHULUAN}

Olahraga adalah suatu aktivitas fisik yang membutuhkan stamina serta didalamnya terdapat sebuah aturan. Olahraga dilihat dari tujuannya dibagi menjadi 1) olahraga prestasi 2) olahraga pendidikan 3) olahraga kesehatan. Di zaman sekarang ini olahraga sudah menjadi suatu profesi pekerjaan bagi sabagian orang. Di Indonesia pun sudah banyak orang yang berprofesi sebagai atlet ataupun serta olahraga dijadikan ajang untuk mencapai sebuah prestasi. Futsal adalah olahraga bola besar yang dimainkan oleh 2 tim setiap tim terdiri 5 orang pemain yang bertujuan untuk mencetak gol kegawang ke lawan. Olahraga futsal memerlukan Teknik, kecepatan, taktik dan fisik yang sangat baik. Teknik wajib dimiliki oleh setiap pemain futsal untuk bermain baik. futsal (futbol sala) dalam bahasa Spanyol berarti sepakbola dalam ruangan yang merupakan permainan sepakbola yang dilakukan didalam ruangan (Lhaksana, 2011). Permainan ini sendiri di lakukan oleh lima pemain setiap tim berbeda dengan sepakbola konvensional yang pemainnya berjumlah sebelas orang setiap tim. Ukuran lapangan dan ukuran bolanya pun lebih kecil dibandingkan ukuran yang digunakan dalam sepakbola rumput (Ghanda Farrell Ibrahim, 2018).

Dalam permainan olahraga futsal maka salah satu yang menjadi bagian didalamnya adalah wasit. Wasit memiliki peranan yang sangat penting dalam suatu pertandingan atau permainan olahraga, terutama didalam olahraga prestasi. Wasit bukan penentu utama dari pertandingan olahraga. Banyak faktor yang mempengaruhi diantaranya pemain, pelatih, lapangan, penonton menjadi bagian dari penentu hasil pertandingan. Menurut BAB VIII pasal 33 sampai dengan pasal 35 tentang peraturanumum pertandingan PSSI, dijelaskan bahwa ada 3 perangkat pertandingan dalam suatu pertandingan sepakbola yang berjalan. Yang mempunyai fungsi masing-masing dalam menjalankan tugas-tugasnya, antara lain: pengawas pertandingan, inspektur wasit, dan wasit. Ketiga komponen ini merupakan komponen perangkat pertandingan yang tidak boleh dilepaskan dari setiap pertandingan yang berjalan karena ketiga komponen tersebut sangat penting, pengawas pertandingan sebagai pengawas jalannya pertandingan, inspektur wasit sebagai evaluasi kinerja wasit, wasit mempunyai wewenang dan tanggung jawab sesuai dengan yang ditentukan PSSI (Khuliman, 2019).

Wasit merupakan suatu hal yang penting dalam pertandingan futsal, maka diharapkan seorang wasit mampu menjalankan tugasnya secara baik dan benar sesuai dengan ketentuan law of the game yang berlaku. Walaupun dalam kenyataannya menjadi seorang wasit itu tidaklah mudah. ada banyak faktor yang harus dikuasai oleh seorang wasit bukan hanya medan lapangan, tetapi banyak faktor eksternal dan internal yang mendukungnya. Wasit pun sering dijadikan pelampiasan oleh para tim yang mengalami kekakalahan bahkan sering dijadikan 
suatu alasan atas kekalahan tim. Dalam permainan futsal ada 2 orang yang bertugas menjadi wasit dilapangan yaitu disebut dengan wasit 1 dan wasit 2 . Sebagai suatu bagian yang sangat penting, seorang wasit diharapkan akan menjalankan fungsinya secara baik dan benar dengan selalu menjunjung tinggi rasa keadilan dan tanggung jawa terhadap terselenggaranya pertandingan. Akan mudahkah seorang wasit menjalankan fungsinya itu? Tentu jawabannya adalah tidak mudah. Salah satu hal yang harus dimiliki seorang wasit yaitu kesiapan mental dan kepercayaan diri yang baik untuk menjalankan fungsinya. Seorang wasit membutuhkan metal yang baik karena selama bertugas seorang wasit sering mendapat tekanan dari para pemain, penonton maupun dari official tim. Kepercayaan diri dibutukan seorang wasit untuk mengatasi situasi dengan baik tanpa bergantung terhadap orang lain dan memiliki evaluasi diri yang baik.

Kepercayaan diri merupakan syarat mutlak pertama yang mesti dimiliki siapapun yang ingin menjadi wasit. Jangan berharap dan bermimpi jadi wasit kalau tidak percaya diri. Ciri pribadi wasit percaya diri adalah: selalu menganggap setiap pemain/atlit/official sejajar dengan dirinya, tidak lebih tinggi dan tidak lebih rendah. Tidak menunduk atau mengangkat kepala, apapun status orang status orang yang dihadapi seperti supporter yang fanatic, manager kaya, tim besar, pemain elite, atau pemain yang biasa.

Menurut (Goel \& Aggarwal, 2012) dalam penelitiaan (Arief Adhitia Hamzah, 2018) menyatakan bahwa kepercayaan diri merupakan kemampuan seseorang untuk mengatasi situasi dengan baik tanpa bergantung pada orang lain dan memiliki evaluasi diri yang positif (Fadlillah, 2020; Karisman, 2017). Selain daripada kepercayaan diri, kesiapan mental menjadi bagian penting bagi seorang wasit. Tingkat kesiapan mental seorang wasit dalam memimpin pertandingan akan berbeda, karena dipengaruhi oleh beberapa hal, baik itu tingkat pertandingannya, suasana penontonnya, maupun kondisi dari wasit itu sendiri. Kesiapan mental merupakan kondisi psikis yang harus dimiliki oleh seorang wasit dalam setiap memimpin pertandingan sehingga diharapkan dalam setiap pengambilan keputusan seorang wasit tidak memiliki keraguan serta yakin akan keputusan yang diambilnya sesuai dengan pemahaman peraturan permainan yang telah dikuasai.

Menurut Gulo kesiapan mental yaitu suatu titik kematangan psikis untuk menerima dan mempraktekkan tingkah laku tertentu. Dipertegas oleh Good kesiapan mental dan sebagai sesuatu kemauan/keinginan tertentu yang tergantung pada tingkat kematangan, pengalaman, dan emosi. Kesiapan menunjukkan pengetahuan, keterampilan dan sikap yang dimiliki seseorang dalam kaitannya dengan keadaan berikutnya yang akan dicapai oleh seseorang (Has, 2018; Tri Sutasmi Nirwan, Muh. Rapi, 2016). Standar kesiapan mental memang tidaklah secara tertulis dijelaskan dalam penilaian kinerja, indikasi kesiapan mental bisa dilihat ketika 
seorang wasit dapat dengan tenang menghadapi suatu tekanan pada saat memimpin pertandingan, sehingga ia tetap dengan fokus menjalankan peraturan permainan dengan baik (Dian Indriansah, 2016).

Berdasarkan uraian penjelasan di atas, penulis merasa tertarik ingin mencari suatu hubungan kesiapan mental dan kepercayaan diri dengan kinerja wasit futsal melalui penelitian di harapkan bisa mengetahui keterkaitan antara kesiapan mental dan kepercaayan diri seorang wasit dalam memimpin dalam suatu petandingan terutama keterkaitanya dengan kinerja seorang wasit dalam memimpin suatu pertandingan.

\section{METODE}

Metode penelitian yang digunakan dalam penelitian ini adalah penelitian kuantitatif kolerasional yang bertujuan untuk mengetahui hubungan antara dua variabel tanpa ada upaya untuk mempengaruhi variabel tersebut. Penelitian korelasional ialah penelitian yang bertujuan untuk mengetahui hubungan antarvariabel atau lebih, tanpa ada upaya untuk mempengaruhi, maka data tersebut valid karena tidak ada manipulasi variabel (Awwaabiin, 2021). Setelah data terkumpul, maka Langkah selanjutnya adalah mengolah data dari setiap angket yang terkumpul dengan menggunakan SPSS 28 for windows.

Penelitian yang digunakan dalam penelitian ini adalah penelitian kuantitatif kolerasional yang bertujuan untuk mengetahui hubungan antara dua variabel tanpa ada upaya untuk mempengaruhi variabel tersebut.

Populasi adalah keseluruhan individu atau objek yang dimaksudkan untuk diteliti dan nantinya akan dikenai generalisasi. Generalisasi adalah suatu cara pengambilan kesimpulan terhadap kelompok individu atau objek yang lebih luas berdasarkan data yang diperoleh dari sekelompok individu atau objek lebih sedikit (Via Diah Rohmana, 2017). Populasi yang digunakan dalam metode penelitian ini adalah seluruh wasit futsal yang masih aktif memimpin pertandingan di kabupaten Bandung Barat sebanyak 9 wasit futsal.

Sampel bagian dari jumlah dari karakteristik yang dimiliki oleh populasi tesebut. Bila populasi besar, dan peneliti tidak mungkin mempelajari semua yang ada pada populasi, misalnya karena keterbatasan dana, tenaga dan waktu, maka peneliti dapat menggunakan sampel yang diambil dari populasi itu. Apa yang dipelajari dari sampel, kesimpulannya akan dapat diberlakukan untuk populasi. Untuk itu sampel yang diambil dari populasi harus betulbetul representatif (mewakili) (Gita, 2017).

Dalam penelitian ini yang dijadikan sampel sebanyak 9 wasit futsal dengan menggunakan teknik total sampling. 
Dalam penelitian ini yang dijadikan sampel sebanyak 9 wasit futsal dengan menggunakan teknik total sampling. Total sampling adalah teknik pengambilan sampel dimana jumlah sampel sama dengan populasi, mengambil total sampling jika sampel yang kurang dari 100 seluruh populasi dijadikan sampel penelitian semuanya (Aminudiin, 2013). Sedangkan sampel yang digunakan untuk uji coba instrumen adalah 10 wasit futsal kota cimahi yang dipilih secara acak. Wasit futsal kota cimahi dipilih sebagai uji coba instrument karena kualitas kinerja wasit futsal kota cimahi tidak jauh berbeda dengan kualitas wasit futsal kabupaten bandung barat.

Adapun angket yang digunakan dalam penelitian ini adalah angket tertutup, maksudnya agar semua jawaban yang diberikan oleh responden lebih mudah untuk dinilai karena semua alternatif jawaban telah ditentukan terlebih dahulu. Alternatif jawaban pada sampel, peneliti menggunakan skala likert atau dikenal dengan skala sikap. Dalam alternatif jawaban setiap butir pernyataan angket diberikan bobot skor skala likert

Desain penelitian adalah suatu strategi untuk mencapai tujuan penelitian yang telah ditetapkan dan berperan sebagai pedoman atau penuntun peneliti pada seluruh proses penelitian. Desain penelitian bagaikan sebuah peta jalan bagi peneliti yang menuntun serta menentukan arah berlangsungnya proses penelitian secara benar dan tepat sesuai dengan tujuan yang telah ditetapkan, tanpa desain yang benar seorang peneliti tidak akan dapat melakukan penelitian dengan baik karena yang bersangkutan tidak mempunyai pedoman arah yang jelas (Hidayat, 2012). Desain penelitian dalam penelitian ini digambarkan sebagai berikut:

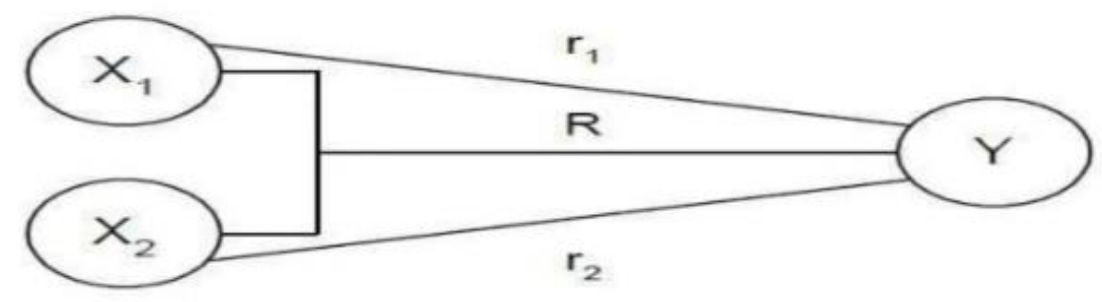

\section{Gambar 1}

Desain Penelitian

(Syahidan, 2014)

Keterangan: 
$\mathrm{X}_{1}$ : Kesiapan Mental

$\mathrm{X}_{2}$ : Kepercayaan diri

Y: Kinerja Wasit

$\mathrm{R}_{1}$ : Hubungan Kesiapan Mental Dengan Kinerja Wasit

$\mathrm{R}_{2}$ : Hubungan Kepercayaan Diri Dengan Kinerja Wasit

R: Hubungan Kesiapan Mental Dan Kepercayaan Diri Dengan Kinerja Wasit

Adapun analisis data mencari korelasi dengan langkah-langkah sebagai barikut: 1) Menyeleksi angket yang terkumpul. Proses ini untuk memastikan seluruh item butir pernyataan diisi oleh responden. 2) Memberikan skor pada tiap butir pernyataan yang disesuaikan dengan kriteria penilaian yang telah ditetapkan. 3) Menginput data dari skor tersebut pada program Microsoft Excel. 4) Selanjutnya mengolah data tersebut dengan pengolahan statistic dengan menggunakan analisis korelasi ganda. Dalam analisis tersebut penulis menggunakan program SPSS 28 for windows.

\section{HASIL DAN PEMBAHASAN}

Data penelitian ini meliputi data yang diperoleh dari pesebaran angket dengan menggunakan skala sikap. Hasil penelitian menunjukan bahwa nilai rata-rata kesiapan mental wasit sebesar 121.67 dengan simpangan baku sebesar 10.65, nilai rata-rata kepercayaan diri wasit sebesar 151.33 dengan simpangan baku sebesar 13.95, dan nilai rata-rata kinerja wasit sebesar 7.92 dengan simpangan baku sebesar 0.59 .

Hasil pengujian normalitas menggunakan uji normalitas Kolmogorov-smirnov menunjukan hasil probabilitas Sig. untuk kesiapan mental sebesar 0.200, probabilitas Sig. kepercayaan diri sebesar 0.200 dan probabilitas kinerja wasit sebesar 0.200. Pengujian mengacu pada perbandingan nilai probabilitas Sig. dengan derajat kebebasan (Dk/Df) yang digunakan 0.05. hal ini berarti bahwa data kesiapan mental, data kepercayaan diri dan kinerja wasit memiliki data yang normal karena hasil perhitungan probabilitas Sig. > 0.05.

Hasil perhitungan data menggunakan korelasi product moment untuk mengetahui tingkat korelasi kesiapan mental $\left(\mathrm{X}_{1}\right)$ dengan kinerja wasit $(\mathrm{Y})$ dan kepercayaan diri $\left(\mathrm{X}_{2}\right)$ dengan kinerja wasit (Y). Melalui perhitungan tersebut menghasilkan angka untuk $\mathrm{rx}_{1} \mathrm{y}$ sebesar 0.695 dengan probabilitas Sig. 0.038 dan $\mathrm{rx}_{2} \mathrm{y}$ sebesar 0.814 dengan probabilitas Sig. 0.008. Dari hasil perhitungan diketahui bahwa probabilitas Sig. kesiapan mental sebesar 0.038 lebih kecil dari $0.05(0.038<0.05)$ berarti terdapat hubungan antara kesiapan mental dengan kinerja wasit futsal dan diketahui bahwa probabilitas Sig. kepercayaan diri sebesar 0.008 lebih kecil dari $0.05(0.008<0.05)$ berarti terdapat hubungan antara kepercayaan diri dengan kinerja wasit futsal. 
Hasil perhitungan regresi ganda bahwa nilai korelasi kesiapan mental $\left(\mathrm{X}_{1}\right)$ dan kepercayaan diri $\left(\mathrm{X}_{2}\right)$ secara bersamaan dengan kinerja wasit futsal $(\mathrm{Y})$ sebesar koefisien determinasi R square sebesar 0.668. Hal ini menunjukan indeks determinasi, yaitu persentase yang menyumbangkan kontribusi dari kesiapan mental dan kepercayaan diri $\left(\mathrm{X}_{1}\right.$ dan $\left.\mathrm{X}_{2}\right)$ berkontribusi sebesar $66.8 \%$ dengan kinerja wasit Futsal, sedangkan sisanya $33.2 \%$ dipengaruhi oleh faktor-faktor lain.

Pada hasil uji korelasi antara kesiapan mental dengan kinerja wasit menghasilkan angka 0.695 dengan probabilitas Sig. 0.038 , hal ini menunjukan tingkat korelasi antara kesiapan mental dengan kinerja wasit futsal adalah kuat. Berikut ini dijelaskan penyebaran data kesiapan mental yang berhubungan dengan kinerja wasit pada gambar 2 .

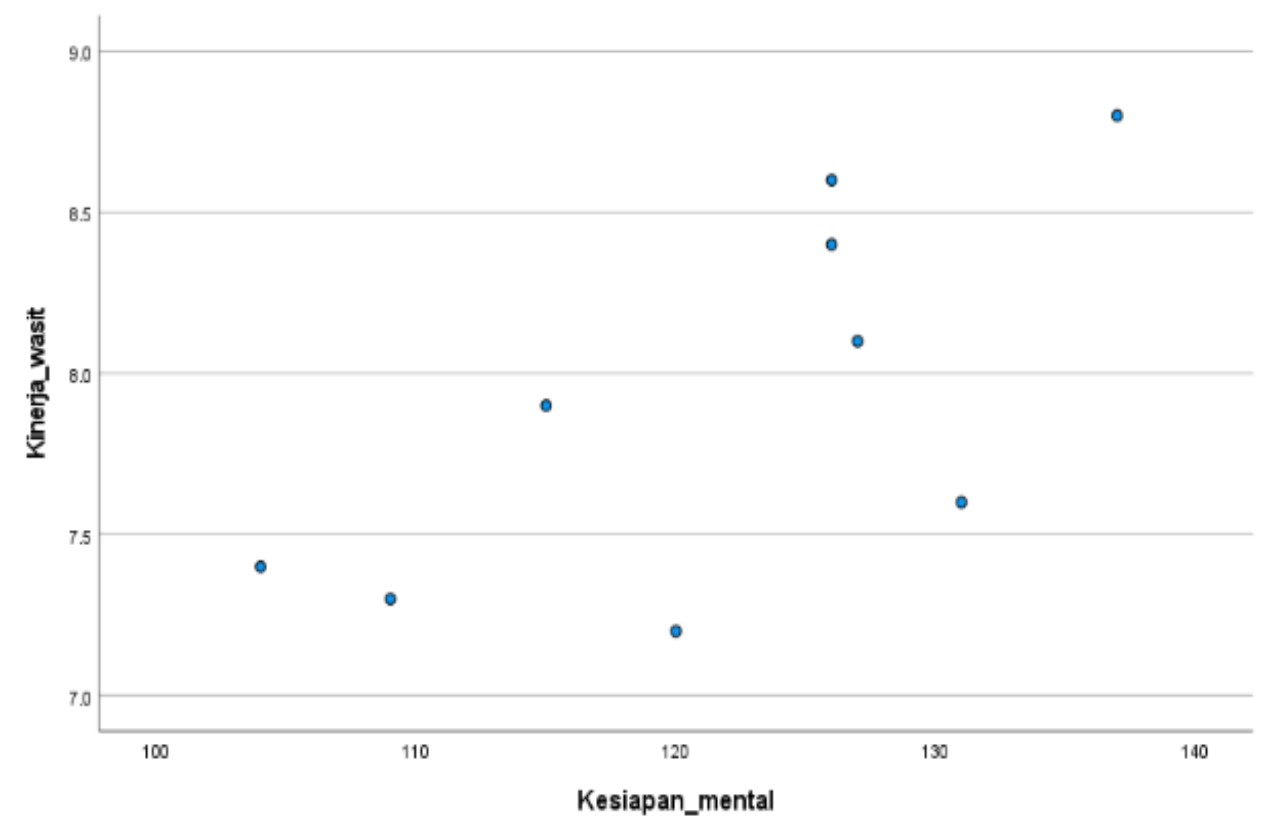

Gambar 2 Uji Kolerasi Kesiapan Mental Dengan Kinerja Wasit

Pada hasil uji korelasi antara kepercayaan diri dengan kinerja wasit menghasilkan angka 0.814 dengan probabilitas 0.008 , hal ini menunjukan tingkat korelasi antara kesiapan mental dengan kinerja wasit futsal adalah sangat kuat. Berikut ini dijelaskan penyebaran data kesiapan mental yang berhubungan dengan kinerja wasit pada gambar 3. 


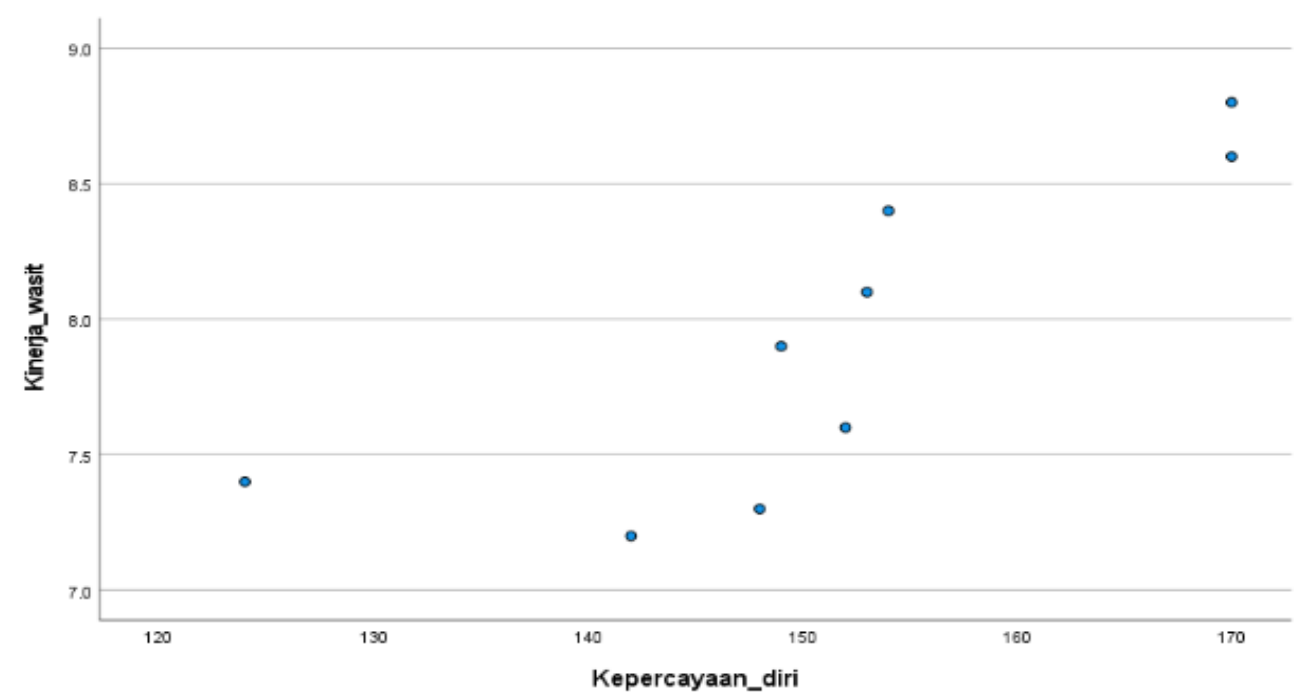

Gambar 3 Uji Kolerasi Kepercayaan Diri Dengan Kinerja Wasit

Koefisien determinasi (R Square atau R kuadrat) yang bermakna sebagai sumbangan pengaruh yang disumbangkan kesiapan mental dan kepercayaan diri terhadap kinerja wasit futsal menghasilkan angka R Square 0.668 dengan probabilitas Sig. 0.037 atau dengan kata lain nilai koefisien determinasi ini berguna untuk memprediksi dan melihat seberapa besar kontribusi pengaruh kesiapan mental dan kinerja wasit secara simultan (Bersama-sama) terhadap kinerja wasit futsal. Hal ini menunjukan tingkat korelasi kesiapan mental dan kepercayaan diri terhadap kinerja wasit futsal sangat kuat. Berikut penjelasan mengenai penyebaran data kesiapan mental dan kepercayaan diri dengan kinerja wasit futsal gambar 4

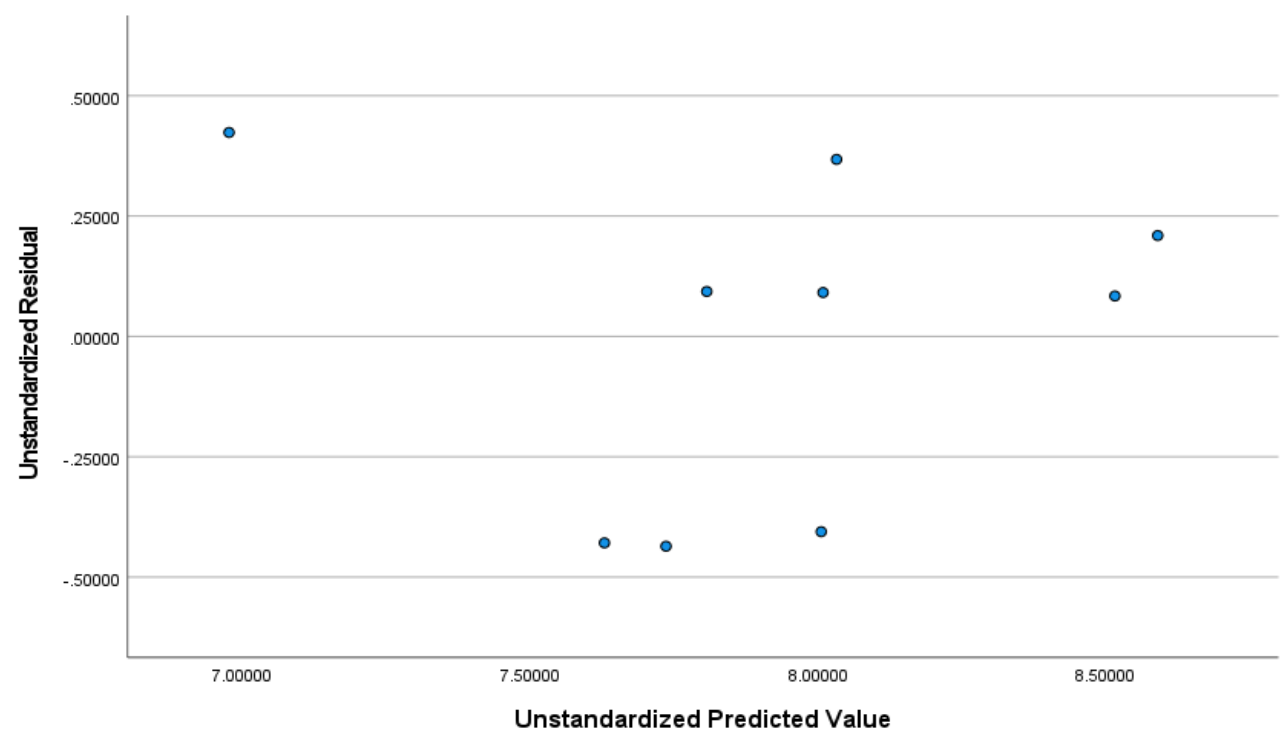

Gambar 4 Uji Kolerasi Kesiapan Mental dan Kepercayaan Diri Dengan Kinerja wasit 
1. Terdapat Hubungan Antara Kesiapan mental dengan kinerja wasit futsal

Dari hasil pengujian diatas dapat disimpulkan bahwa terdapat hubungan kesiapan mental dengan kinerja wasit futsal. Hasil penelitian ini sejalan dengan penelitian (Dian Indriansah, 2016) yang menyimpulkan Wasit yang memiliki kesiapan mental yang baik akan memimpin dengan tegas dan penuh tanggung jawab tidak mudah goyah ketika menghadapi protes dari pemain serta teguh terhadap setiap keputusan yang diambil.

Kesiapan mental adalah keseluruhan kondisi seseorang yang membuatnya siap untuk memberi respon/jawaban di dalam acara tertentu terhadap suatu situasi (Has, 2018). Bahwa dalam pertandingan, kesuksesan sedikitnya ditentukan oleh $70 \%$ faktor mental dan hanya $30 \%$ faktor yang lain (Dian Indriansah, 2016).

\section{Terdapat Hubungan Kepercayaan Diri Dengan Kinerja Wasit Futsal}

Dari hasil pengujian di atas dapat disimpulkan bahwa terdapat hubungan kepercayaan diri dengan kinerja wasit futsal. Hal ini sejalan dengan penelitian (Arief Adhitia Hamzah, 2018) yang menyimpulkan Bahwa dalam memimpin suatu pertandingan wasit harus memiliki tingkat kepercayaan diri yang tinggi, maka dari itu kinerja wasit dalam memimpin pertandingan akan semakin baik. Sebaliknya apabila seorang wasit kurang memiliki rasa percaya diri, maka dalam memimpin pertandingan akan kurang sehingga kemungkinan melakukan berbagai kesalahan dapat terjadi.

Kepercayaan diri merupakan suatu sikap atau perasaan yakin atas kemampuan yang dimiliki individu yang bersangkutan sehingga individu yang bersangkutan tidak terlalu cemas dalam setiap Tindakan, dapat bebas melakukan hal-hal yang disukai dan bertanggung jawab atas segala perbuatan yang dilakukan, hangat dan sopan dalam berinteraksi dengan orang lain (Deni \& Ifdil, 2016). Percaya diri (Self Confidence) adalah meyakinkan pada kemampuan dan penilaian (judgement) diri sendiri dalam melakukan tugas dan memilih pendekatan yang efektif (Rizki, 2019).

3. Terdapat Hubungan Antara Kesiapan Mental Dan Kepercayaan Diri Dengan Kinerja Wasit Futsal

Dari hasil pengolahan data dan analisis data diperoleh bahwa koefisien korelasi antara variabel tingkat kesiapan mental (X1) dengan kinerja wasit futsal (Y) sebesar 0.695, ini berarti ada hubungan yang kuat dan positif antara variabel tingkat kesiapan mental dengan kinerja wasit.

Successful football referees' activity include many aspects of game/match such as game knowledge, decision-making skills, psychological skills, strategies skills, communication skills, and physical fitness (Rahman Arief, 2016). Keberhasilan seorang wasit dalam memimpin suatu pertandingan banyak ditentukan oleh beberapa aspek seperti kebugaran (Physical 
Fitness) (Bryantara, 2016), kemampuan dalam membaca permainan, kemampuan dalam pengambilan keputusan, kemampuan psikologis, kemampuan dalam berkomunikasi dan kemampuan penempatan posisi yang baik. Menurut (Komarudin, n.d.) aspek-aspek keterampilan psikologis di dalamnya yaitu keterampilan mental, motivasi, kesadaran diri, penetapan tujuan, kepercayaan diri, imagery, self-talk, perhatian dan konsentrasi (M. A. Komarudin, 2019).

\section{KESIMPULAN}

Berdasarkan hasil pengolahan dan analisis data mengenai hubungan kesiapan mental dan kepercayaan diri dengan kinerja wasit futsal yang dilakukan di kabupaten Bandung Barat dapat ditarik kesimpulan sebagai berikut:

1. Dari hasil pengolahan data dan analisis data diperoleh bahwa koefisien korelasi antara variabel tingkat kesiapan mental (X1) dengan kinerja wasit futsal (Y) sebesar 0.695, ini berarti ada hubungan yang kuat dan positif antara variabel tingkat kesiapan mental dengan kinerja wasit.

2. Dari hasil pengolahan data dan analisis data diperoleh bahwa koefisien korelasi antara variabel tingkat kepercayaan diri (X2) dengan kinerja wasit futsal (Y) sebesar 0.814, ini berarti ada hubungan yang sangat kuat dan positif antara variabel tingkat kepercayaan diri dengan kinerja wasit.

3. Nilai kolerasi kesiapan mental $\left(\mathrm{X}_{1}\right)$ dan kepercayaan diri $\left(\mathrm{X}_{2}\right)$ secara bersamaan dengan kinerja wasit futsal $\left(\mathrm{Y}_{1}\right)$ sebesar koefisien determinasi R Square sebesar 0.668. hal ini menunjukan indeks determinasi, yaitu persentase yang menyumbangkan kontribusi dari kesiapan mental dan kepercayaan diri $\left(\mathrm{X}_{1}\right.$ dan $\left.\mathrm{X}_{2}\right)$ berkontribusi sebesar $66.8 \%$ dengan kinerja wasit futsal, sedangkan sisanya $33.2 \%$ dipengaruhi oleh faktor-faktor lain.

\section{DAFTAR PUSTAKA}

Aminudiin, A. K. (2013). GAMBARAN PENGETAHUAN REMAJA TENTANG PORNOGRAFI PADA SISWA KELAS VIII DI SMPN LEMBANG. 25-33.

Arief Adhitia Hamzah. (2018). HUBUNGAN ANTARA TINGKAT KECEMASAN, KEPERCAYAAN DIRI, DAN PENGAMBILAN KEPUTUSAN DENGAN KINERJA WASIT FUTSAL DALAM MEMIMPIN PERTANDINGAN.

Awwaabiin, S. (2021). Penelitian Korelasional: Pengertian, Ciri-ciri, Langkah, dan Contoh. DEEPUBLISH.

Bryantara. (2016). Faktor Yang Berhubungan Dengan Kebugaran Jasmani (VO2 Maks) Atlet 
Sepakbola. Jurnal Berkala Epidemiologi. Jurnal Berkala Epidemiologi, 4(2), 237-249. https://doi.org/10.20473/jbe.v4i2.2016.237

Deni, A. U., \& Ifdil. (2016). Konsep Kepercayaan Diri Remaja Putri. Jurnal Educatio: Jurnal Pendidikan Indonesia, 2(2), 43-52.

Dian Indriansah. (2016). Dian Indriansah, 2016 Hubungan Antara Kondisi Fisik, Kesiapan Mental, dan Pemahaman Peraturan dengan Kinerja Wasit Futsal Universitas Pendidikan Indonesia| repository.upi.edu| perpustakaan.upi.edu. 32-47.

Fadlillah, I. A. (2020). Hubungan rasa percaya diri siswa dengan hasil belajar kognitif siswa dalam pembelajaran daring pada materi sistem gerak: Penelitian di kelas VIII MTs. Manba 'ul Huda Bandung tahun ajaran 2020/2021. UIN SUNAN GUNUNG DJATI BANDUNG.

Ghanda Farrell Ibrahim. (2018). PENGEMBANGAN MODEL LATIHAN SHOOTING FUTSAL MELALUI MEDIA APLIKASI BERBASIS ANDROID PADA USIA 14 - 18 TAHUN.

Gita, D. I. D. (2017). Deliana Iman Dwi Gita, 2017 HUBUNGAN TINGKAT KEBUGARAN DENGAN KINERJA WASIT FUTSAL LIGA NUSANTARA 2017. 22-29.

Has, Z. (2018). PENGARUH CARA BELAJAR DAN KESIAPAN MENTAL SISWA TERHADAP HASIL BELAJAR SISWA KELAS XI IPS SMA NEGERI 1 PANGKALAN KURAS KABUPATEN PELALAWAN. 6(2), 135-141.

Hidayat, A. (2012). Penjelasan Desain Penelitian. Statistikian.

Karisman, V. A. (2017). IMPLEMENTASI PENDIDIKAN REKREASI DAN OUTDOOR TERHADAP PERCAYA DIRI MAHASISWA. Jurnal Kependidikan Jasmani Dan Olahraga, $1(91), 56-61$.

Khuliman, M. T. (2019). PERWASITAN SEPAKBOLA ASKOT PSSI KOTA SEMARANG TAHUN 2018 .

Komarudin, M. A. (n.d.). Pengantar Psikologi Olahraga. 1-29.

Rahman Arief. (2016). HUBUNGAN ANTARA KEBUGARAN, KECERDASAN INTELEKTUAL, DAN KECERDASAN EMOSIONAL DENGAN KINERJA WASIT FUTSAL LEVEL 1 KOTA BANDUNG. 1-9.

Rizki, R. (2019). HUBUNGAN TINGKAT KEBUGARAN JASMANI DAN SIKAP PERCAYA DIRI TERHADAP MINAT MENGIKUTI EKSTRAKURIKULER OLAHRAGA DI SD NEGERI SE- 
KECAMATAN SELOMERTO KABUPATEN WONOSOBO TAHUN 2017/2018.

Syahidan, R. (2014). Materi Statistika 2: Kolerasi Ganda. Mathematics E-Lerning Syahidan27.

Tri Sutasmi Nirwan, Muh. Rapi, M. (2016). HUBUNGAN ANTARA KESIAPAN MENTAL DENGAN MOTIVASI BELAJAR PADA MATA PELAJARAN BIOLOGI Tri. 4(36), 33-51.

Via Diah Rohmana, D. C. K. (2017). PENGARUH TINGKAT PERCAYA DIRI TERHADAP KINERJA WASIT BOLA BASKET ( Studi Pada Wasit UKM Bola Basket Universitas Negeri Surabaya) Via Diah Rohmana Dwi Cahyo Kartiko Abstrak. 5(3), 573-578. 